\title{
Comparative skull morphology of two pika species (Ochotona princeps and O. hyperborea): implications for differences in feeding habits
}

\author{
Shohei Matsunami, Tatsuo Oshida* \& Hideo Ichikawa
}

\begin{abstract}
To examine the hypothesis that cranium and mandible morphology influence different feeding habits in pikas, we compared two samples: Ochotona princeps from California and Nevada, USA and $O$. hyperborea from Hokkaido, Japan. These pika species show similar ecological traits, are allopatrically distributed in Northern Hemisphere, and inhabit rocky hillsides on mountain. Of all measurements, $55 \%$ showed no significant differences, indicating the two samples had similarly sized and shaped skulls. Measurements with significant differences were related to origins and terminations of chewing muscles. Morphological differences between these two samples may result from differences in feeding habits.
\end{abstract}

KEY WORDS: American pika, northern pika, chewing muscles, cranium, mandible

Shohei Matsunami, Laboratory of Wildlife Ecology, Obihiro University of Agriculture and Veterinary Medicine, Obihiro 080-8555, Japan [present address: Laboratory of Animal Behavior and Intelligence, Department of Biology, Faculty of Science Hokkaido University]; Tatsuo Oshida [oshidata@obihiro.ac.jp], Laboratory of Wildlife Ecology, Obihiro University of Agriculture and Veterinary Medicine, Obihiro 080-8555, Japan; Hideo Ichikawa, Botanic Garden, Field Science Center for Northern Biosphere, Sapporo 060-0003, Japan

\section{Сравнительная морфология черепа двух видов пищух (Ochotona princeps and O. hyperborea): различия в пищевой специализации}

\section{Ш. Матсунами, Т. Ошида, Х. Ичикава}

\begin{abstract}
РЕЗЮМЕ: Для проверки влияния пищевой специализации на морфологию черепа и нижней челюсти было проведено сравнение двух выборок пищух: Ochotona princeps из Калифорнии и Невады, США и O. hyperborea с о-ва Хоккайдо, Япония. Эти виды пищух сходны по экологии и аллопатрически распространены в Северном Полушарии, населяя каменистые склоны гор. По 55\% промеров не обнаружено различий между видами, что свидетельствует о сходных размерах и морфологии черепа обоих видов. Промеры, показывающие наибольшие различая, связаны с местами крепления жевательных мышц. Эти морфологические различия могут свидетельствовать о разной пищевой специализации исследованных видов.
\end{abstract}

КЛЮЧЕВЫЕ СЛОВА: американская пищуха, северная пищуха, жевательные мышцы, череп, нижняя челюсть.

\section{Introduction}

There is a direct correlation between feeding characteristics and skull morphology in mammals (e.g., Feldhamer et al., 2004). This correlation is among genera, families, and orders, as well as within species and among closely related species. For instance, the differences in skull morphology among populations of raccoon dog Nyctereutes procyonoides may result from the differences in their carnivorous diets (Kauhala et al., 1998). There is a correlation between feeding type and mandibular corpus height in populations of sika deer Cervus nippon (Ozaki et al., 2006). Examination

*Corresponding author of skull morphology helps to explain environmental adaptation of feeding habits in mammals.

To examine how skull shape changed with feeding habits, we compared with skull measurements of two pika species: the American pika Ochotona princeps and the northern pika $O$. hyperborea. In the Northern Hemisphere, 31 Ochotona species are identified (Wilson $\&$ Reeder, 2005). Of them, we selected two allopatric species ( $O$. princeps and $O$. hyperborea) based on distribution, external characteristics, and habitat.

Ochotona princeps occurs in the western part of North America. Ochotona hyperborea is widely distributed in northern part of Eurasia, Sakhalin Island of Russia, and Hokkaido Island of Japan (Abe et al., 2005; Wilson \& Reeder, 2005). The external characteristics 
of Ochotona princeps are very similar to those of $O$. hyperborea (Smith \& Weston, 1990). In fact, these two species, and other two species (O. alpina and $O$. colaris), have been treated as a single species (O. alpina) (Argiropulo, 1948; Gureev, 1964; Corbet, 1978). In addition, both species inhabit rocky banks in mountain areas, showing similar ecological traits (e.g., Smith et al., 1990).

These two species, however, are not closely related to each other (Niu et al., 2004; Lissovsky et al., 2007). The similar morphological and ecological characteristics between them may indicate adaptive convergence for a specific habitat. Although both species commonly inhabit rocky banks, the vegetation spectrum in $O$. hyperborea habitat is so huge and various that is covers not only $O$. princeps's spectrum, but some additional species also. The spectrum of $O$. hyperborea in Hokkaido Island, however, is different from that of $O$. princeps. Any significant differences in skull measurements, such as mandible height, are likely to result from differences in feeding behavior, as a resulted from differences in vegetation.

Of all Ochotona species, the food habits of these two species are well studied: $O$. princeps mainly uses grasses, forbs, and cushion plants (Huntly et al., 1986) and lichens (Conner, 1983), and O. hyperborea also feeds grasses and forbs (Inukai, 1931; Sakagami et al., 1956; Haga, 1960). The food resources of two pika species, however, evidently differ in species of plants. These differences in food may affect the shape of cranium and mandible associated with chewing muscles. For instance, jaw muscles of pika species that successfully eat more indigestible resources may be more powerfully developed, and this may affect the shape of mandible because jaw muscles attach directly the mandible. Although it is difficult to morphologically compare different species because each species may have geographic variations (Lissovsky, 2003), we preliminary discuss how differences in skull and mandible morphology influenced food habits in these two pika species by using the respective local sample.

\section{Materials and methods}

We examined 31 skulls of Ochotona princeps and 18 skulls of $O$. hyperborea (Appendices 1 and 2). To avoid the influences of geographic variation on morphological characteristics, we used each local sample in this study: sample of $O$. princeps was from California and Nevada, USA and that of $O$. hyperborea was from Hokkaido, Japan. These specimens are deposited in the
University of California Museum of Vertebrate Zoology, Berkeley; the Museum of Botanic Garden of Hokkaido University, Sapporo; the National Science Museum, Tokyo; the Mt. Apoidake Visitor Center, Samani; the Higashi Taisetsu Museum of Natural History, Nukabira; and the Laboratory of Wildlife Ecology, Obihiro University of Agriculture and Veterinary Medicine, Obihiro. We considered all specimens adults because of the degree of closure of cranial structures and the presence of a sagittal crest. Measurements of skulls of American pikas older than one year indicate no size differences between sexes (Weston, 1981; Smith \& Weston, 1990). Therefore, we combined the sexes for this examination.

We followed the definitions of Abe (1991) and Otsuka et al. (1980) for the 19 cranial and mandible measurements included in this study (Fig. 1): greatest length (GL), nasal length (NL), condylobasal length $(\mathrm{CBL})$, basilar length (BL), palatal length (PL), upper diastema length (UD), length of upper tooth row (LUT), mastoid breadth (MB), zygomatic breadth (ZB), interorbital breadth constriction (IBC), rostrum breadth (RB), distance between first upper premolars (PMD1), breadth across upper tooth rows (BTM), distance between first upper molars (MD1), minimum length of auditory bulla (LAB1), maximum length of auditory bulla (LAB2), mandible height (MH), length of mandible (LM), and length of lower tooth row (LLT). For more detailed morphological information, we added 17 measurements: length from postnarial anterior margin to basilar bone (PABB), length of basilar bone (BB), distance between temporal foveae (TF), length between temporal fossa and zygomaticotemporal process (TFZP), distance between processes of upper part of zygomatic arch (PZA), breadth of frontal bone (FB), distance between unique processes (UP) of anterior part of zygomatic bone (PAZB), minimum length between lateral margins of maxillae (LMM), breadth across occipital condyles (BOC), maximum length of aditus orbitae (LAO), maximum length across auditory bullae (LAAB), height of cranium (HC), distance between UP and lateral margin of zygomatic bone (UPZB), breadth of condyloid process (BCP), breadth of angle of the mandible (BAM), length from angular process to incisive alveolus (APIA), and lower diastema (LD). All of measurements were taken to the nearest 0.01 using $\mathrm{mm}$ by digital calipers.

To estimate differences in skull size between two local samples, we compared each variable with a Student's $t$-test. Principal component analysis (PCA) and stepwise discriminate analysis clarified variation between two samples for cranial and mandible measure-

(BB), distance between temporal fossae (TF), length between temporal fossa and zygomaticotemporal process (TFZP), distance between processes of upper part of zygomatic arch (PZA), breadth of frontal bone (FB), distance between unique processes (UP) of anterior part of zygomatic bone (PAZB), minimum length between lateral margins of maxillae (LMM), breadth across the occipital condyles (BOC), maximum length of aditus orbitae (LAO), maximum length across auditory bullae (LAAB), height of cranium (HC), distance between UP and lateral margin of zygomatic bone (UPZB), breadth of condyloid process (BCP), breadth of angle of the mandible (BAM), length from angular process to incisive alveolus (APIA), and lower diastema (LD). Figure was adapted from Abe (2000). 

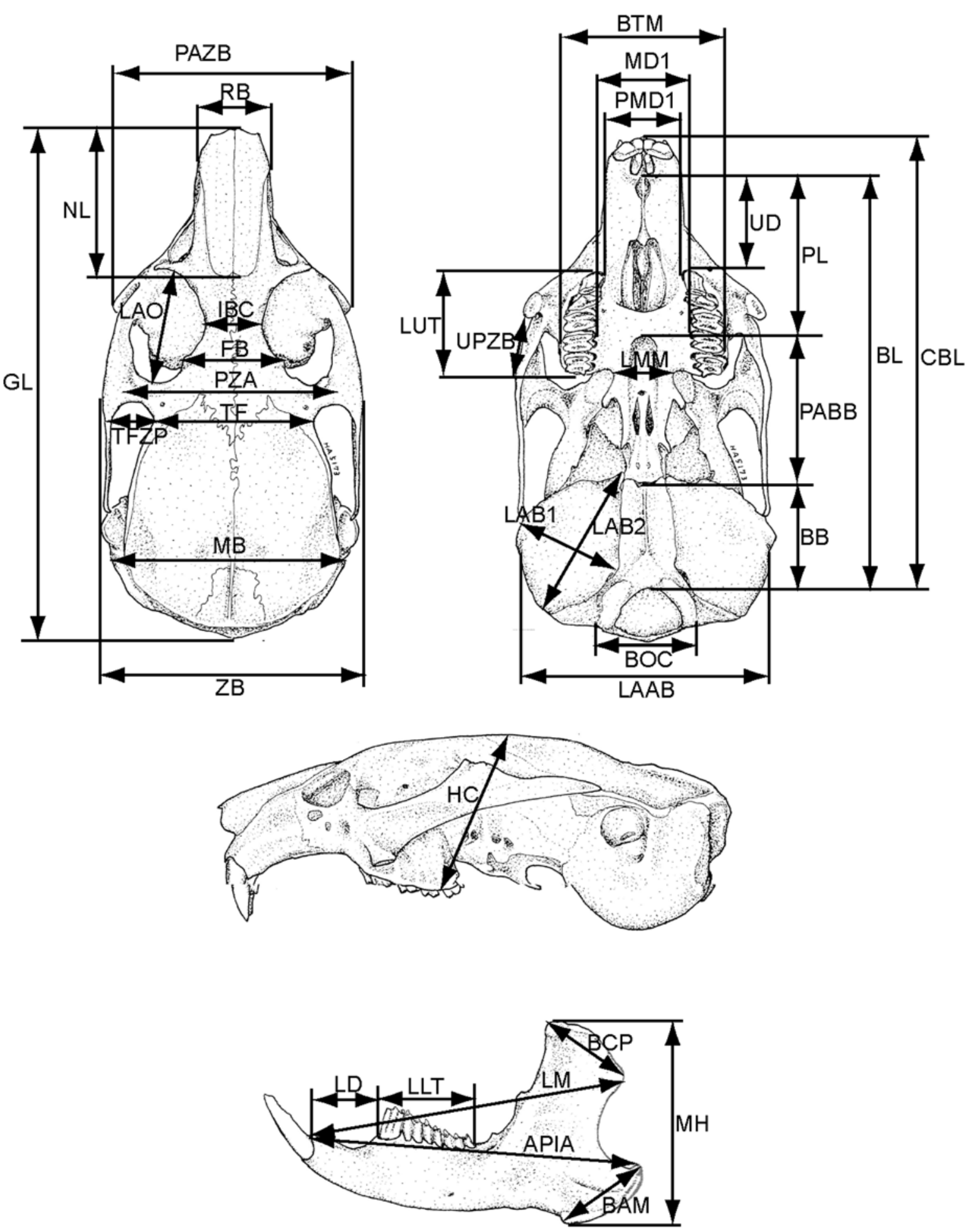

Figure 1. Skull measurements in Ochotona princeps and O. hyperborea. Greatest length (GL), nasal length (NL), condylobasal length (CBL), basilar length (BL), palatal length (PL), upper diastema (UD), length of upper tooth row (LUT), mastoid breadth $(\mathrm{MB})$, zygomatic breadth (ZB), interorbital breadth constriction (IBC), rostrum breadth (RB), distance between first upper premolars (PMD1), breadth across upper tooth rows (BTM), distance between first upper molars (MD1), minimum length of auditory bulla (LAB1), maximum length of auditory bulla (LAB2), mandible height (MH), length of mandible (LM), and length of lower tooth row (LLT). In addition to these measurements, to resolve more highly the morphological information, we used 17 measurements: length from postnarial anterior margin to basilar bone (PABB), length of basilar bone 
Table 1. The skull measurements ( $\mathrm{mm}$ ) of Ochotona princeps and O. hyperborea (n: number of specimens, mean, and SD: standard deviation) and results of t-test $(P)$. Abbreviations corresponded to those in Fig. 1. $* P<0.05$, ** $P<0.01$, *** $P<$ 0.001 , and ns: $P>0.05$.

\begin{tabular}{|c|c|c|c|c|c|c|c|}
\hline \multirow{2}{*}{ Variable } & \multicolumn{3}{|c|}{ O. princeps } & \multicolumn{3}{|c|}{ O. hyperborea } & \multirow[b]{2}{*}{$p$} \\
\hline & $\mathrm{n}$ & mean & SD & $\mathrm{n}$ & mean & SD & \\
\hline GL & 27 & 40.83 & 0.91 & 17 & 41.45 & 1.26 & $\mathrm{~ns}$ \\
\hline NL & 31 & 12.28 & 0.52 & 17 & 12.42 & 0.59 & ns \\
\hline CBL & 25 & 34.59 & 1.10 & 14 & 35.75 & 0.83 & $* *$ \\
\hline $\mathrm{BL}$ & 25 & 31.87 & 0.99 & 14 & 32.92 & 0.79 & $* *$ \\
\hline PL & 29 & 13.19 & 0.54 & 17 & 13.10 & 0.45 & ns \\
\hline PABB & 27 & 10.15 & 0.45 & 14 & 11.02 & 0.26 & *** \\
\hline $\mathrm{BB}$ & 25 & 7.90 & 0.40 & 14 & 8.04 & 0.35 & ns \\
\hline UD & 31 & 7.70 & 0.39 & 18 & 7.71 & 0.26 & ns \\
\hline LUT & 31 & 8.05 & 0.34 & 18 & 7.98 & 0.31 & ns \\
\hline MB & 26 & 17.86 & 0.79 & 17 & 17.60 & 0.60 & ns \\
\hline TF & 26 & 13.57 & 0.32 & 17 & 12.93 & 0.42 & $* * *$ \\
\hline TFZP & 30 & 3.42 & 0.22 & 17 & 3.56 & 0.16 & $*$ \\
\hline ZB & 25 & 20.53 & 0.52 & 17 & 20.80 & 0.44 & $\mathrm{~ns}$ \\
\hline PZA & 26 & 15.90 & 0.43 & 18 & 15.05 & 0.36 & $* * *$ \\
\hline FB & 28 & 9.11 & 0.37 & 18 & 7.79 & 0.58 & $* * *$ \\
\hline IBC & 30 & 5.15 & 0.38 & 18 & 4.57 & 0.34 & $* * *$ \\
\hline $\mathrm{RB}$ & 31 & 5.48 & 0.27 & 18 & 5.52 & 0.31 & $\mathrm{~ns}$ \\
\hline PMD1 & 29 & 5.73 & 0.26 & 17 & 6.06 & 0.24 & *** \\
\hline PAZB & 25 & 18.84 & 0.60 & 16 & 19.16 & 0.55 & ns \\
\hline ВTM & 28 & 7.16 & 0.37 & 17 & 7.33 & 0.25 & $\mathrm{~ns}$ \\
\hline MD1 & 28 & 12.02 & 0.41 & 18 & 12.15 & 0.29 & $\mathrm{~ns}$ \\
\hline LMM & 27 & 4.86 & 0.18 & 17 & 4.71 & 0.23 & $* *$ \\
\hline LAAB & 22 & 19.82 & 0.50 & 14 & 19.75 & 0.54 & ns \\
\hline BOC & 27 & 7.57 & 0.31 & 15 & 7.58 & 0.25 & $\mathrm{~ns}$ \\
\hline LAO & 31 & 9.27 & 0.30 & 18 & 9.31 & 0.24 & $\mathrm{~ns}$ \\
\hline LAB1 & 27 & 7.78 & 0.45 & 15 & 7.62 & 0.32 & $\mathrm{~ns}$ \\
\hline LAB2 & 27 & 12.48 & 0.53 & 15 & 12.70 & 0.35 & ns \\
\hline $\mathrm{HC}$ & 30 & 12.35 & 0.41 & 17 & 12.01 & 0.73 & $*$ \\
\hline UPZB & 30 & 6.23 & 0.57 & 18 & 7.54 & 1.04 & *** \\
\hline $\mathrm{BCP}$ & 27 & 6.42 & 0.35 & 16 & 7.01 & 0.32 & **** \\
\hline BAM & 28 & 7.74 & 0.59 & 16 & 7.74 & 0.55 & $\mathrm{~ns}$ \\
\hline LM & 27 & 26.28 & 0.88 & 15 & 26.87 & 0.62 & $*$ \\
\hline APIA & 27 & 25.98 & 0.92 & 17 & 27.31 & 1.28 & $* *$ \\
\hline MH & 28 & 15.85 & 0.53 & 15 & 16.87 & 0.50 & $* * *$ \\
\hline LLT & 31 & 7.80 & 0.26 & 17 & 7.76 & 0.26 & ns \\
\hline LD & 31 & 5.74 & 0.27 & 17 & 5.79 & 0.41 & $\mathrm{~ns}$ \\
\hline
\end{tabular}


ments. All statistical analyses were performed with the JMP IN (SAS Institute Inc., 2004).

\section{Results}

Six skull measurements (TF, FB, PZA, LMM, IBC, and $\mathrm{HC}$ ) were significantly larger for $O$. princeps than for $O$. hyperborea (Student's $t$-test, $P<0.05$ : Tab. 1). In contrast, ten skull measurements (CBL, BL, PABB, TFZP, MD1, UPZB, BCP, LM, APIA, and MH) were significantly smaller for $O$. princeps than for $O$. hyperborea (Student's $t$-test, $P<0.05$ : Tab. 1 ).

In a PCA using all cranial and mandible measurements, the 1 st and 2 nd principal component axes explained $40.3 \%$ and $16.7 \%$ of the total variation, respectively (Tab. 2). These two principle components adequately separated the two local species (Fig. 2). On the 1st principle component, variables GL, CBL, BL, ZB, LAAB, LAB2, BAM, LM, APIA, and MH were somehow heavily loaded. On the 2nd principle component, variables TF, PZA, FB, and IBC were heavily positive and variables PABB and UPZB were heavily negative (Tab. 2).

A stepwise discriminant analysis selected eight variables in this order: FB, PMD1, LAB1, BCD, BAM, LAAB, LLT, BTM, APIA, and PZA. These variables correctly classified $100 \%$ of the skulls by species (Fig. 3).

\section{Discussion}

The 20 measurements (55\% of all measurements) showed no significant differences between the two samples $(P>0.05)$ for measurements comparison. Especially, as there were no significant differences in some major values to represent essential external trait of skulls such as greatest length (GL), zygomatic breadth

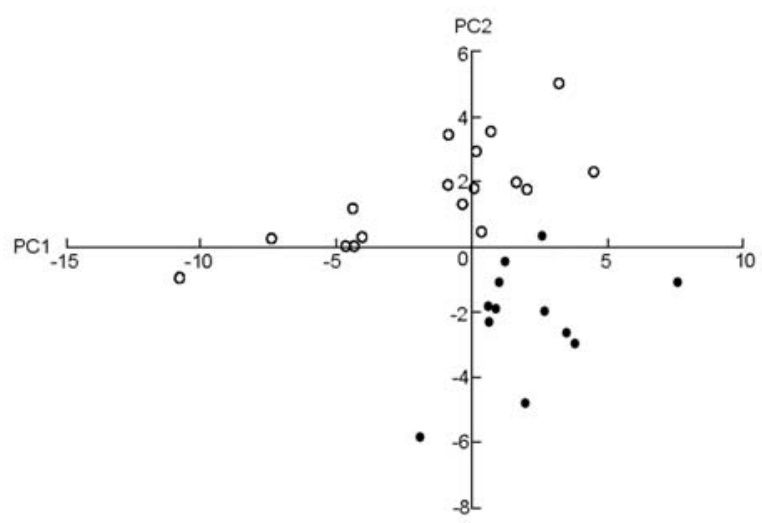

Figure 2. First (PC1) and second (PC2) principle components of principle component analysis of skull measurements of Ochotona princeps (solid circles) and O. hyperborea (open circles).
Table 2. First principal component (PC1) and second principal component (PC2) of skull comparing skull measurements of Ochotona princeps and O. hyperborean. Abbreviations corresponded to those in Fig. 1.

\begin{tabular}{|l|r|r|}
\hline Variable & PC1 & PC2 \\
\hline GL & 0.2392 & 0.0325 \\
NL & 0.1218 & 0.1340 \\
CBL & 0.2484 & -0.0551 \\
BL & 0.2469 & -0.0526 \\
PL & 0.1688 & 0.1637 \\
PABB & 0.1567 & -0.2575 \\
BB & 0.1592 & 0.0069 \\
UD & 0.1467 & 0.1613 \\
LUT & 0.1684 & 0.1036 \\
MB & 0.1613 & 0.1824 \\
TF & -0.0304 & 0.3397 \\
TFZP & 0.1534 & -0.0791 \\
ZB & 0.2265 & 0.0725 \\
PZA & -0.0191 & 0.3509 \\
FB & -0.1101 & 0.3432 \\
IBC & -0.0086 & 0.3349 \\
RB & 0.1684 & 0.0435 \\
PMD1 & 0.1652 & -0.0892 \\
PAZB & 0.1978 & 0.0375 \\
BTM & 0.1762 & 0.0740 \\
MD1 & 0.1839 & 0.0442 \\
LMM & 0.0841 & 0.2483 \\
LAAB & 0.2110 & 0.1323 \\
BOC & 0.0581 & -0.1032 \\
LAO & 0.1360 & -0.0387 \\
LAB1 & 0.2113 & 0.0520 \\
LAB2 & 0.0765 & 0.1954 \\
HC & 0.0098 & 0.2345 \\
UPZB & 0.1485 & -0.2599 \\
BCP & 0.1968 & -0.1502 \\
BAM & 0.0616 \\
LM & -0.0052 \\
APIA & -0.0720 \\
\hline
\end{tabular}




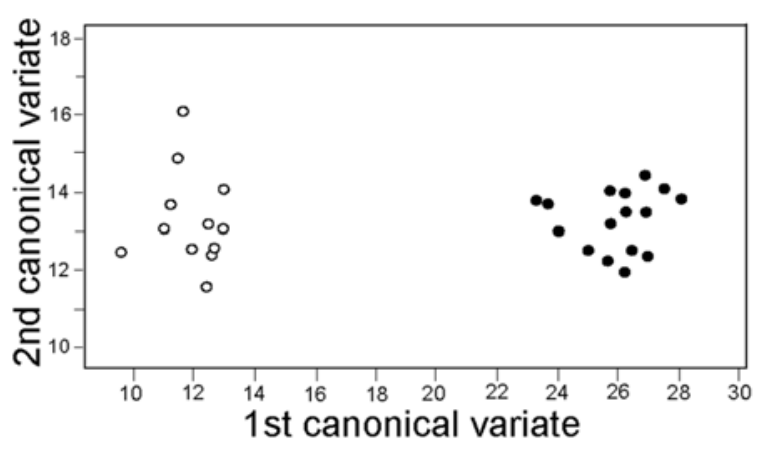

Figure 3. Stepwise discriminant analysis of 36 cranial and mandible measurements of Ochotona princeps (solid circles) and $O$. hyperborea (open circles).

(ZB), and mastoid breadth (MB), two samples could have similar skull in both size and shape.

Principle component analysis and discriminant analysis of skulls, however, showed clear separation in the two samples (Figs 2 and 3). Ochotona princeps has larger TF, FB, PZA, IBC, LMM, and HC. Of them, TF, $\mathrm{FB}, \mathrm{PZA}$, and IBC were also loaded heavily positively in principle component analysis as a second principle component. The FB was first selected in discriminant analysis. Larger TF, FB, PZA, and IBC mean that the upper part of cranium of $O$. princeps could be wider than that of $O$. hyperborea.

In contrast, O. hyperborea has larger CBL, BL, PABB, TFZP, MD1, UPZB, BCP, LM, APIA, and $\mathrm{MH}$. The APIA and BAM were selected in discriminant analysis. The PABB was heavily negatively loaded in principle component analysis as a second principle component. The larger $\mathrm{CBL}, \mathrm{BL}$, and $\mathrm{PABB}$ explain that under part of cranium of $O$. hyperborea could be longer than those of $O$. princeps, in spite of no significant differences in GL. Moreover, the larger BCP, LM, APIA, and $\mathrm{MH}$ mean that $O$. hyperborea could have larger mandible.

The TF of $O$. hyperborea was significantly shorter than that of $O$.princeps. This measurement may reflect differences in chewing behavior between the two samples. The temporal muscle originates from the temporal fovea and terminates at the condyloid process of mandible (e.g., Kato, 1979; Popesko et al., 1992). If the TF is narrower, the temporal muscle may have more increased beside temporal bone. Narrowing of PZA and FB may be helpful in increasing temporal muscle. The IBC is also closely associated to the origin of the temporal muscle. This muscle may have increased on the narrower postorbital constriction of $O$. hyperborea. The longer $\mathrm{CBL}, \mathrm{BL}$, and $\mathrm{PABB}$ in O. hyperborea may indicate that some bones in the cranium, especially the sphenoid bone, are longer. The external pterygoid muscle (necessary for mastication) originates from pterygoid process of sphenoid bone, and terminates at condyloid process of mandible (Kato, 1979). Moreover, the internal pterygoid muscle originates from pterygoid process of sphenoid bone, palatine bone, and pterygoid bone, and terminates at pterygoid of mandible (Kato, 1979). As sphenoid bone lengthens, these pterygoid muscles can increase in size. Moreover, the larger mandible of $O$. hyperborea could be result of development of the masseter muscle. This muscle widely attaches with the mandible (Kato, 1979).

Although both pikas are herbivorous, O. hyperborea from Hokkaido may have more developed chewing muscles than $O$. princeps from California and $\mathrm{Ne}-$ vada. By adapting its feeding behavior to utilize the environment (vegetation), O. hyperborea from Hokkaido may have developed larger temporal muscle and evolved narrower IBC and TF, longer CBL, BL, and $\mathrm{PABB}$, and larger mandible.

We suggest that differences in skull characteristics were related to feeding behavior. This should be tested for different Ochotona species with different feeding behaviors. Since we compared local sample of $O$. princeps to that of $O$. hyperborea (Appendices 1 and 2), intra-specific differences should be examined using different populations living in different environments. Moreover, to clarify the relationship in Ochotona between muscle development and skull shape and size, chewing muscles should be anatomically examined.

ACKNOWLEDGEMENT. We greatly thank C. J. Conroy (University of California Museum of Vertebrate Zoology), S. Kawada (National Science Museum), H. Abe (Hokkaido University), M. Kawabe (Higashi Taisetsu Museum of National History), T. Nakagawa (Fishery Center, Erimo Town Museum), and M. Tanaka. We thank H. Yanagawa and S. Nakama for helpful comments. We thank C. L. Bridgman for reading the entire manuscript in its original form.

\section{References}

Abe H. 1991. [Measurement and specimen preparation] // Kusano T., Mori H., Ishibashi N. \& Y. Fujimaki Y, (eds.). Laboratory and Field Experiments for Applied Zoology. Tokyo: Zenkoku Noson Kyoiku Cooperative. P.10-17 [in Japanese].

Abe H. 2000. Illustrated Skulls of Japanese Mammals. Sapporo: Hokkaido University Press. 279 p. [in Japanese].

Abe H., Ishii N., Ito T., Kaneko Y., Maeda K., Miura S. \& Yoneda M. 2005. A Guide to the Mammals of Japan. Kanagawa: Tokai University Press. 206 p.

Aho K., Huntly N., Moen J. \& Oksanen T. 1998. Pikas (Ochotona princeps: Lagomorpha) as allogeneic engineers in an alpine ecosystem // Oecologia. Vol.114. P.405-409.

Argiropulo A.I. 1948. A review of recent species of the family Lagomyidae Lilljeb., 1886 (Lagomorpha, Mammalia) // Trudy Zoologicheskogo Instituta AN SSSR. Vol.7. P.124-128 [in Russian].

Conner D.A. 1983. Seasonal changes in activity patterns and the adaptive value of haying in pikas (Ochotona princeps) // Canadian Journal of Zoology. Vol.61. P.411-416.

Corbet G.B. 1978. The Mammals of the Palearctic Region: A Taxonomic Review. British Museum (Natural History). New York: Cornel University Press. 314 p. 
Dearing M.D. 1996. Disparate determinants of summer and winter diet selection of a generalist herbivore, Ochotona princeps // Oecologia. Vol.108. P.467-468.

Feldhamer G.A., Drickamer L.C., Vessey S.H. \& Merritt J.F. 2004. Mammalogy: Adaptation, Diversity, and Ecology, Second Edition. New York: McGraw-Hill. 550 p.

Gureev A.A. 1964. Fauna of the USSR. Mammals. Vol.3. Part 10, Lagomorpha. Moskva: Nauka. 275 p. [In Russian].

Haga R. 1960. Observations on the ecology of the Japanese pika // Journal of Mammalogy. Vol.41. P.200-212.

Huntly N.J., Smith A.T. \& Ivins B.L. 1986. Foraging behavior of the pika (Ochotona princeps), with comparison of grazing versus haying // Journal of Mammalogy. Vol.67. P.139-148.

Inukai T. 1931. A food-hoard of Ochotona from Taisetsuzan, the central mountains of Hokkaido // Transactions of Sapporo Natural History Society. Vol.11. P.210-214.

Kato Y. 1979. [The Illustrated Comparative Anatomy of Domestic Animals] Tokyo: Youkendo. 661 p. [in Japanese].

Kauhala K., Viranta S., Kishimoto M., Helle E. \& Obara I. 1998. Skull and tooth morphology of Finnish and Japanese raccoon dogs // Annales Zoologici Fennici Vol.35. P.1-16.

Lissovsky A.A. 2003. Geographic variation of skull characters in pikas (Ochotona Lagomorpha) of the alpinahyperborea group // Acta Theriologica. Vol. 48. P.1124.

Lissovsky A.A., Ivanova N.V. \& Borisenko A.V. 2007. Molecular phylogenetics and taxonomy of the subgenus Pika (Ochotona, Lagomorpha) // Journal of Mammalogy. Vol.88. P.1195-1204.

Niu Y., Wei F., Li M., Liu X. \& Feng Z. 2004. Phylogeny of pikas (Lagomorpha, Ochotona) inferred from mitochon- drial cytochrome $b$ sequences // Folia Zoologica. Vol.52. P.141-155.

Otsuka J., Toyomitsu Y. \& Nishinakagawa H. 1980. Linear measurements of the bones of Lepus brachyurus brachyurus Temminck, Pentalagus furnessi Stone and Oryctolagus cuniculus Linnaeus (JW-NIBS) // Experimental Animal. Vol.29. P.441-455.

Ozaki M., Suwa G., Kaji K., Ohba T., Hosoi E., Koizumi T. \& Takatsuki S. 2006. Correlation between feeding type and mandibular morphology in the sika deer // Journal of Zoology. Vol.272. P.244-257.

Popesko P., Rajtová V. \& Horák J. 1992. A Colour Atlas of the Anatomy of Small Laboratory Animals 2: Rat, Mouse, Golden Hamster. London: Wolfe Publishing Ltd. 253 p.

Sakagami S., Mori H. \& Kikuchi H. 1956. Miscellaneous observations on a pika, Ochotona sp. inhabiting near the lake Shikaribetsu, Taisetsuzan National Park, Hokkaido // Japanese Journal of Applied Zoology. Vol.21. P.1-9.

SAS Institute Inc. 2004. JMP Start Statistics. Third Edition. Cary: SAS Institute Inc.

Smith A.T., Formozov N.A., Hoffmann R.S., Changlin Z. \& Erbajeva M.A. 1990. The Pikas // Chapman J.A. \& Flux J.E.C. (eds.). Rabbits, Hares and Pikas: Status Survey and Conservation Action Plan. Oxford: IUCN. P.14-60.

Smith A.T. \& Weston M.L. 1990. Ochotona hyperborea // Mammalian Species. No.352. P.1-8.

Weston M.L. 1981. The Ochotona alpina complex: a statistical re-evaluation // K. Myers K. \& MacInnes C.D. (eds.). Proceedings of the World Lagomorph Conference. Ontario: Guelph University Press. P.73-89.

Wilson D.E. \& Reeder D.M. 2005. Mammal Species of the World: a Taxonomic and Geographic Reference. 3rd ed. Baltimore: The Johns Hopkins University Press. 2142 p.

Appendix 1. Thirty-one specimens of Ochotona princeps examined in the present study. All specimens were used through the loan system of Museum of Vertebrate Zoology, University of California.

\begin{tabular}{|l|l|l|l|l|l|}
\hline Identitiy number & Sex & Collecting locality & Identitiy number & Sex & Collecting locality \\
\hline MVZ Mamm105609 & male & Mono Co., California & MVZ Mamm105629 & male & Mono Co., California \\
MVZ Mamm105610 & male & Mono Co., California & MVZ Mamm105630 & male & Mono Co., California \\
MVZ Mamm105611 & male & Mono Co., California & MVZ Mamm105631 & male & Mono Co., California \\
MVZ Mamm105612 & female & Mono Co., California & MVZ Mamm105632 & male & Mono Co., California \\
MVZ Mamm105613 & male & Mono Co., California & MVZ Mamm105635 & female & Mono Co., California \\
MVZ Mamm105614 & male & Mono Co., California & MVZ Mamm105637 & male & Mono Co., California \\
MVZ Mamm105615 & male & Mono Co., California & MVZ Mamm105662 & female & Mono Co., California \\
MVZ Mamm105616 & female & Mono Co., California & MVZ Mamm105663 & male & Mono Co., California \\
MVZ Mamm105617 & male & Mono Co., California & MVZ Mamm105664 & male & Mono Co., California \\
MVZ Mamm105618 & male & Mono Co., California & MVZ Mamm107330 & female & Mineral Co., Nevada \\
MVZ Mamm105619 & female & Mono Co., California & MVZ Mamm107332 & female & Mineral Co., Nevada \\
MVZ Mamm105620 & male & Mono Co., California & MVZ Mamm107334 & female & Mineral Co., Nevada \\
MVZ Mamm105621 & male & Mono Co., California & MVZ Mamm107335 & female & Mineral Co., Nevada \\
MVZ Mamm105622 & female & Mono Co., California & MVZ Mamm135058 & female & Mono Co., California \\
MVZ Mamm105626 & female & Mono Co., California & MVZ Mamm135064 & female & Mono Co., California \\
MVZ Mamm105628 & female & Mono Co., California & & & \\
\hline
\end{tabular}


Appendix 2. Eighteen specimens of Ochotona hyperborea examined in the present study.

\begin{tabular}{|c|c|c|c|}
\hline Institute & Identitiy number & Sex & Collecting locality \\
\hline National Science Museum & $\begin{array}{l}\text { M8524 } \\
\text { M8738 }\end{array}$ & $\begin{array}{l}\text { female } \\
\text { unknown }\end{array}$ & $\begin{array}{l}\text { Hokkaido, Japan } \\
\text { Hokkaido, Japan }\end{array}$ \\
\hline Hokkaido University & $\begin{array}{l}24676 \\
24677 \\
24679 \\
42944 \\
43373 \\
50298 \\
54845 \\
55173 \\
\end{array}$ & $\begin{array}{l}\text { unknown } \\
\text { unknown } \\
\text { unknown } \\
\text { unknown } \\
\text { unknown } \\
\text { unknown } \\
\text { unknown } \\
\text { unknown }\end{array}$ & $\begin{array}{l}\text { Hokkaido, Japan } \\
\text { Hokkaido, Japan } \\
\text { Hokkaido, Japan } \\
\text { Hokkaido, Japan } \\
\text { Hokkaido, Japan } \\
\text { Hokkaido, Japan } \\
\text { Hokkaido, Japan } \\
\text { Hokkaido, Japan }\end{array}$ \\
\hline $\begin{array}{l}\text { Obihiro University of Agriculture and } \\
\text { Veterinary Medicine }\end{array}$ & $\begin{array}{l}1 \\
2 \\
3 \\
4 \\
6 \\
7 \\
\end{array}$ & $\begin{array}{l}\text { female } \\
\text { male } \\
\text { female } \\
\text { female } \\
\text { male } \\
\text { female }\end{array}$ & $\begin{array}{l}\text { Hokkaido, Japan } \\
\text { Hokkaido, Japan } \\
\text { Hokkaido, Japan } \\
\text { Hokkaido, Japan } \\
\text { Hokkaido, Japan } \\
\text { Hokkaido, Japan }\end{array}$ \\
\hline Higashi Taisetsu Museum of Natural History & Higashi 01 & unknown & Hokkaido, Japan \\
\hline Apoi Mountain Visitor Center & Apoi 01 & unknown & Hokkaido, Japan \\
\hline
\end{tabular}

